\title{
ANÁlise CRÍTICA dO MERCADO DE TRABALHO DE ESTADO DE SÃO PAULO: UMA COMPARAÇÃO ENTRE INDICADORES DE TRABALHO, ANTES E DEPOIS DA REFORMA TRABALHISTA.
}

\author{
Orientada: Carolina Franchini Santiago \\ Orientador: José Dari Krein
}

\section{Resumo}

Para compreender os desdobramentos de alguns fatos no presente, muitas vezes, é necessário estudar o passado com o intuito de compreender a evolução do fenômeno que se quer estudar. O mercado de trabalho, no Brasil, principalmente até os anos 1980 era limitado e a abertura econômica trouxe a expansão das fronteiras, em diversos aspectos - positivos e negativos. O principal objetivo deste projeto é analisar a evolução de indicadores de trabalho (emprego, desemprego, renda e informalidade) dos últimos 5 anos, ou seja, a partir de 2012 e confrontar estes dados com os dados provenientes do período posterior ao da reforma trabalhista. Este projeto de pesquisa está inserido na Rede de Estudos e Monitoramento da Reforma Trabalhista (REMIR - Trabalho), esta rede foi criada com o objetivo crítico e analítico de compreender a regulamentação e sistematização das relações de trabalho no Brasil.

\section{Palavras-chave:}

Reforma Trabalhista, Emprego, Informalidade.

\section{Introdução}

Dado o atual momento de desenvolvimento e situação da economia brasileira, para este projeto denota-se importância estrutural pessoal, tendo em vista os novos caminhos da política brasileira. Tratando do período a partir dos anos 1980 foi de grande mudança na estrutura econômica brasileira, grande parte desse processo de reestruturação e novas fronteiras, foi estabelecido por meio da abertura econômica - intensificada, principalmente, a partir dos anos 1990 (PAULI, et. al. 2012).

As alterações no modelo produtivo vigente, assim como a introdução de novas tecnologias trazidas por empresas provenientes do exterior acabaram gerando alterações no tipo de ocupação e no padrão de regulação das relações de trabalho vigente no País. Foi uma dinâmica que resultou em uma desindustrialização do país e de fortaleceu o setor de serviços e do agronegócio, o que tende a gerar postos de trabalho que exigem menor nível de qualificação e com salários mais baixos. (PAULI, et. al, 2012).

\section{Resultados e Discussão}

Os dados da PNAD Continua foram analisados e trazem aspectos que são relativos ao desenvolvimento do nível de desemprego; formação de empregos com carteira assinada e sem carteira assinada nos setores privado, doméstico e público; população subocupada.

Gráfico 1. Evolução da taxa de população desocupada, 2012 - 2019.

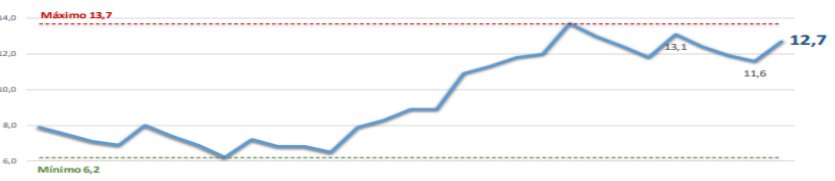

Comparando com o Estado de São Paulo, um dos Estados mais ricos e populosos da Federação, nota-se que a taxa de desocupação está acima da média nacional e no $4^{\circ}$ trimestre de 2018 atinge cerca de $13,5 \%$.

Gráfico 2: Nível de emprego com/sem carteira assinada por setor, $2012-2019$.

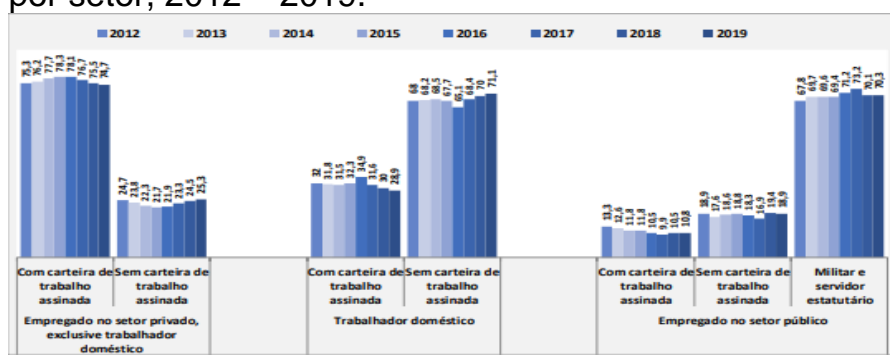

O gráfico mostra a grande disparidade que existe nas relações empresariais especialmente dentro do setor privado e doméstico, assim como as reduções dos empregos com carteira assinada ao longo dos últimos anos.

\section{Conclusões}

A discrepância entre os setores chama atenção. A evolução do emprego não ocorreu da maneira em que foi indicada pelo relatório da Comissão Especial criada no senado, assim como a sua formalização dentro do Mercado de trabalho. Estima-se que a reforma apenas desfavoreceu ainda mais a balança para o trabalhador, reduzindo diretos e aumentando obrigações.

\section{Agradecimentos}

Gostaria de Agradecer a minha família, aos meus professores e ao PIBIC e UNICAMP.

ALMEIDA, T. B. A. de. Flexibilização das normas trabalhistas enquanto instrumento de mudança nas relações de trabalho. 2016.

BIAVASCHI, M. B.. A reforma trabalhista no Brasil de Rosa: propostas que não criam empregos e reduzem direitos. 2017.

BIAVASCHI, M. B.. A reforma trabalhista no Brasil de Rosa: propostas que não criam empregos e reduzem direitos. 2017 